\title{
A universidade, a escola e as necessidades especiais: como melhorar? Como contribuir?
}

\section{The university, the school and the special needs: how to improve, how to contribute?}

\section{Resumo}

\author{
Cristina M.C. Delou ${ }^{1}$ \\ Isabelle Mazza ${ }^{2}$ \\ Lourena Marinho ${ }^{2}$ \\ Ruth Mariani ${ }^{3}$ \\ Carlos R. Rodrigues ${ }^{4}$ \\ Helena Carla Castro ${ }^{5}$
}

\begin{abstract}
Um dos principais objetivos de qualquer programa educacional de governo é educar os cidadáos para serem comprometidos com toda a sociedade. Para garantir o acesso a todos à educação, os professores precisam atender com qualidade todos os alunos, inclusive aqueles com necessidades especiais. No entanto, a falta de informação e formaçáo profissional continua sendo ainda um dos principais obstáculos para alcançar este objetivo. A Escola de Inclusão é um programa de extensão de uma universidade federal brasileira e aborda diferentes áreas (ex: direitos humanos, educação e saúde), estimulando a interação de professores e licenciandos. Seus objetivos incluem a produção de materiais de ensino inclusivos e tecnologia educacional, a formaçáo continuada de professores e a criaçáo de conhecimento e de condiçóes de acessibilidade para os alunos com necessidades especiais. Neste trabalho o nosso objetivo foi analisar brevemente a estratégia deste programa que considera os profissionais de educação, os estudantes de graduação (licenciandos) e alunos com necessidades especiais, como o melhor público para a construção e/ou avaliação do seu material didático. Interessantemente, a nossa análise qualitativa sobre os relatos de professores, alunos de graduação e um estudante do ensino médio cego, que participaram de ediçóes desse programa, reforçam que projetos de universidades podem ser capazes de contribuir para a formaçáo de profissionais, de alunos de graduaçáo e de ensino médio, enquanto aproximam o público-alvo da perspectiva do professor. Esta iniciativa também sugere que os alunos com necessidades especiais podem participar ativamente de sua própria educação se as instituiçôes aprenderem a estimulá-los a um comportamento pró-ativo.
\end{abstract}

Pavavras-chave: inclusão, educação, necessidades especiais, educação especial.

\section{Abstract}

One main purpose of any governmental educational program is to educate citizens to be committed to the whole society. To ensure that everyone has access to education, professors need to attend with quality all students including those with special needs. However, the lack of training and professional information is still one main obstacle for reaching this goal. The Escola de Inclusão is an extension program from a Brazilian Federal university and approaches different areas (e.g. human rights, education and health) stimulating the interaction between teachers and undergraduates. Its goals include the production of inclusive teaching materials and educational technology, the teachers continuing formation and the creation of knowledge and accessibility conditions for students with special needs. In this work our purpose was to analyze this program strategy that considers the educational professionals, the undergraduate students and students with special needs as the best public to construct andlor evaluate the educational material produced. Interestingly, our qualitative analysis regarding the reports of teachers, undergraduates and a high school blind student that participated in the program's late editions inferred the contribution of universities projects for education of professionals, undergraduate and high school students whereas bring the target audience closer to the teacher perspective. This initiative also suggests that students with special needs can actively participate in their own formal education if the institutions learn how to stimulate them to a pro-active behavior

Keywords: environmental education, interdisciplinary, Education.

\footnotetext{
${ }^{1}$ Doutora, Professora associada II da Universidade Federal Fluminense (UFF)

${ }^{2}$ Mestranda do Programa de Biologia das Interaçóes da Universidade Federal Fluminense (UFF)

${ }^{3}$ Doutoranda do Programa de Biologia das Interaçóes da Universidade Federal Fluminense (UFF)

${ }^{4}$ Doutor, Professor Associado da Universidade Federal do Rio de Janeiro (UFRJ)

${ }^{5}$ Doutora, Professora associada da Universidade Federal Fluminense (UFF)
} 


\section{INTRODUCTION}

Education is an important process not only for the full individual development but also for the preparation to the exercise of citizenship. In Brazil, education of people with special needs should be held preferably in the regular school system. More recently, the Special Education, once viewed as a form of education of people with special needs, is now a part of the Brazilian Basic and Higher Education (BRAZIL, 2011).

However, few Brazilian schools have educational strategies for inclusion of people with special educational needs, particularly for visually impaired ones (ARRUDA, 2008, BUENO, 2004). The homogeneity of the didactical materials and teaching methods for visual approaching significantly affect the inclusion of visually impaired individuals in the educational process (CERQUEIRA E FERREIRA, 1996, BEVERIDGE, 2005). Unfortunately, these factors have not been considered as decisive in the formation of the educational professionals that teach this public. According to the literature, there are books and studies on this subject in the human sciences area but not in the areas of biological, biomedical and technological sciences, where the lack of information about teaching and inclusive material design methods is still significant (BRAZIL, 2004).

Any teacher who has experienced the challenge of teaching visually impaired students knows the issues for reaching this task (KYRIACOU, 1995). In fact, the absence of educational resources that are essential for teaching them is one of the worst problems to solve (AINSCOW et al., 2004, DUMPEL, 2011).

Currently, questions regarding teaching visually impaired students about human body features as well as biology, physics, chemistry or geography topics still remain. The methods used for teaching these technological disciplines are based primarily on visual models, which amplify the difficult of learning complex topics (DAVIS and FLORIAN, 2004).

The transformation of visual information in tactile information to be recognized by a visually impaired person is not that easy and involves a high degree of complexity to show levels of information (WRIGHT, 2008). The techniques involved are not taught in universities in a formal way or in any way at all in most of the Brazilian educational institutions (MAZZOTA, 2005). Unfortunately, unprepared professionals of these specific areas are still being formed in Brazil despite the Brazilian law guarantees the access of education for all, thus implying the participation of well prepared educational professionals (KYRIACOU, 1995; BRAZIL, 2011).

When a person visually identifies the objects, the image might reveal equally the size, texture and movement concepts, among other properties. For a visually impaired person, this information is obtained by touch, sound, and/ or smell (GRIFIN and GERBER, 1996).

The tactile perception is not as integrative vision form, but fragmented and, therefore, slow (GRIFIN and GERBER, 1996). In addition, the presence of the object is detected only when it can be heard, smelled or touched. These senses are related to time and space. Therefore, simultaneous viewing of objects in a space with multiple objects is frequently not possible (nor mentally imagined) to those adapted to a sequential perception by touch. For the visually impaired, the idea of space can be incomprehensible (CERQUEIRA E FERREIRA, 1996).

Recently, the use of two and three-dimensional models or tactual images as additional resources to illustrate the educational texts has been investigated (FLORIAN, 2005 and 2008). Some authors have evaluated the features of tactile perception by blind children and adolescents and observed its importance for this public (DUMPEL, 2011).

There are no textbooks available in this knowledge field regarding the correlation between cognitive knowledge gained by touch or by hearing with their actual representation. Thus this is an educational space that needs to be filled properly and scientifically. In addition, the requirement of new educational strategies that use 3D-representation of biological structures to help a visually impaired person may also help other students (SASSAKI, 2005; PEREIRA, 2011).

The use of tactile models as a strategy for helping on the teaching-learning process of the themes of biology may be important for the inclusion of visually impaired people in personal and social context considering that: a) one principle of education is to guarantee citizens equal conditions for access and permanence at school, and b) information obtained through tactile contact with objects of various shapes and sizes can help in meaningful learning of all students (VIVEIROS AND CAMARGO, 2006). Importantly, the target audience is still an important issue when producing didactical materials. Thus the question about how producing materials without the target audience previous evaluation, in this case the student with special needs, is still an issue to solve (STAKES AND HORNBY, 2000).

The visually impaired people are individuals whose knowledge should be accessible and must be stimulated. At the same time, the inclusive material production at the university should allow us to use this opportunity also to contribute on forming not only of the target audience, but also the future graduates, teachers and professors (FLORIAN, 2008).

The Escola de Inclusão is an extension program from the Universidade Federal Fluminense, a Brazilian federal university (PROEX, 2011). Its main purpose is to (in)form undergraduates, teachers and professors and people from go- 
vernmental and non-governmental organizations for the use of languages and codes applicable to individuals who have the difficulty on communicating and signaling and for the production of accessible teaching materials or dissemination of knowledge in specific areas such biology, to achieve professional training in formal (public and private schools) and non-formal (museums, cultural centers and home) education. Four short courses are offered simultaneously: Braille, Brazilian Sign Language (LIBRAS), Applied construction of accessible Instructional Materials and Basic Themes on Inclusive Education, which underlie the new teaching practices.

In this work we aim to analyze briefly the concepts of teachers, undergraduates and a high school blind student after the participation in Escola de Inclusão. We also intend to identify its ability of producing educational technology as well as training educational professionals and creating conditions for encouraging the participation of students with special needs.

\section{MATERIALS AND METHODS}

\section{Construction of models}

The three-dimensional or two-dimensional models using low cost and recycled materials were produced by professors and undergraduates in four editions (years 2010 and 2011) of Escola de Inclusão, the extension program of the Universidade Federal Fluminense coordinated by Drs. Cristina Delou (Faculty of Education - UFF) and Helena Carla Castro (Institute of Biology - UFF).

\section{EVALUATION BY STUDENT WITH SPECIAL EDUCATIONAL NEEDS}

The evaluation of the models was made by the professors and undergraduates that participate of the extension program as well by a state high school student of 18 years, blind since early adolescence. The tests involved the tactile assessment of didactical models as educational tools for the understanding of specific topics in biology. The student also evaluated the ability of the model to reveal differences in size, texture and shape of the structures as described by Dumpel (2011).

\section{RESULTS AND DISCUSSION}

Among the materials that have been created in the Escola de Inclusão, some biological themes were addressed by undergraduates, professors and teachers (Figure 1A). Seve- ral inclusive didactical materials regarding biological topics were produced by them in the late editions of the extension program.

Tactile Atlas (e.g. Human Body Systems, Human Physiology, Circulatory System, Digestive System and the Fungi kingdom), games (e.g. Metabolism, Chemical Adapted Bingo, Memory in Braille for teaching French, Portuguese and Literature, Adapted Tic Tac Toe, Memory in LIBRAS, Adapted ImuneChess, Game "What Is That Area?"), Tactile Books (e.g. Cells in isotonic medium, Chemistry in Comics, Smell it), Models (e.g. Cells, Reproductive System in hermaphrodite flowers, Embryology, Stem Cells, Blood Types, Male reproductive system), Tactile plates (e.g. Brazilian Climate Map, World Map, Guidance - Wind Rose, Theory of Continental Drift and Tectonics plate, Hereditary captaincy, Layout Cell Division, Border Rivers) and Textured puzzles (e.g. Logical Block, Phylum Arthropoda) were produced by the undergraduates, teachers and professors.

Here we showed the digestive and respiratory syste$\mathrm{ms}$, the muscle bundle and its connection to the nervous system, and a story involving ecological issues (Figure 1). These materials were evaluated by the blind student that collaborate with the program whose blindness allowed him to exploit them in their maximum capacity of reaching students with visual impairments (Figure 1). His sensitivity and perception cannot be imitated or lived faithfully trusted by any of us who are capable of seeing (Table 1). Thus this preliminary evaluation is clearly needed to ensure the quality of these materials as a didactical tool for visually impaired people.

The analysis of the individual opinions suggested that the creation and analysis of inclusive materials not only contributed to the training of undergraduates and teachers but also to the high school blind student involved in the program (Table 1).

Interestingly, the first written report of the high school blind student about his analysis of the material produced in the program showed a high textual formality (Table 1) when compared to his oral speech. It is worth mentioning that this language was not induced or encouraged in any way by any member of the project. This infers that the student considers the analysis of these material prototypes as something important and decisive for their establishment as final teaching materials.

Importantly, the Escola de Inclusão experiences integrated the university and high school and allowed the formation of important connections between these two educational environments. It reduced their distance and approached the future teachers to their target audience. This perspective is especially important when it comes to include the student with special needs. These results also suggested that the 
links university-school and teacher-student contribute not only to produce creative didactical materials, but also for the integration of the educational professionals (teachers) and the future professional (undergraduates). In addition, the current approach with the blind student primarily allows students with special needs to be considered more than a problem in the classroom, but someone who may contribute with their own training. They may help their teachers and professors since they may participate in projects in a pro-active context of teaching and learning.

The Escola de Inclusão strategy can be repeated in any higher education institution, public or private, and associated with any school of any grade level, public or private, in any region. The multiplication of efforts to integrate students with and without special needs with their pro-active participation in the teaching and learning process (including working as a mentor in the materials evaluation) is one of the strategies that can be clearly used for stimulating their participation and formation.

\section{ACKNOWLEDGEMENTS}

We thank PROEX-UFF, FAPERJ, CNPq and CAPES for the financial support and fellowships.

\section{REFERÊNCIAS BIBLIOGRÁFICAS}

1. AINSCOW, M.; BOOTH, T.; DYSON, D. Understanding and developing inclusive practices in schools: a collaborative action research network. Int. J. Inclusive Educ., 8, p.125-139, 2004.

2. ARRUDA, S.M.C.P. Acessibilidade no cotidiano de pessoas com deficiência visual. Revista Ambiente Educação, 1, p.113-121, 2008.

3. BEVERIDGE, S. Special educational needs in schools (2nded.). London: Routledge. Centre for Studies on Inclusive Education (CSIE) Children before choice: Bristol: CSIE, 2005.

4. BRASIL. CONSELHO NACIONAL DE EDUCAÇÃO/CÂMARA DE EDUCAÇÃO BÁSICA. Resoluçáo N.o 02/2001. disponível no site http://portal.mec. gov.br/seesp/arquivos/pdf/res2_b.pdf, consulta em 2011.

5. BUENO, J.G.S. Educação Especial Brasileira: Integraçáo/segregação do aluno diferente. (2a ed.). São Paulo: EDUC-Fapesp, 2004.
6. CERQUEIRA, B.J.; FERREIRA, B.M.E. Os recursos didáticos na educaçáo especial. Revista Benjamin Constant, 5, 1996. Disponível no site http://www.ibc. gov $\cdot$ br $/$ ?catid $=4 \&$ itemid $=47$.

7. DAVIS, P.; FLORIAN L. Teaching strategies and approaches for pupils with special educational needs: a scoping study. Nottingham: DfES, 2004.

8. DUMPEL, R. Modelos de células interativos: facilitadores na compreensáo das estruturas celulares e no processo de inclusáo de indivíduos com necessidades educacionais especiais visuais. Dissertação defendida no Programa de Pós-graduação em Ensino de Biociências e Saúde (PGEBS). Acessado em http://ensino.ioc.fiocruz. br/teses/site/detalhamento.asp?id=EBS-MP-089, 2011.

9. FLORIAN, L. 'Inclusion', 'special needs' and the search for new understandings. Support for Learning, 20, p.96-98, 2005.

10. FLORIAN, L. Special or inclusive education: future trends. British J. Special Educ., 35, p.202-208, 2008.

11. GRIFIN, H.C.; GERBER, P.J. Desenvolvimento tátil e suas implicaçóes na educaçáo de crianças cegas. Revista Benjamin Constant. 5, 1996. Disponível no site http:// www.ibc.gov.br/?catid=4\&itemid=47. Acesso em 2011.

12. KYRIACOU, C. Essential teaching skills (2nd ed.) Padstow; Stanley Thornes (Publishers) Ltd,1995.

13. MAZZOTTA, M. J.S. A Educação Especial no Brasil.5. a ed. São Paulo: Cortez, 2005.

14. PEREIRA, W.S.B. Um Passeio na Educação do Cego. Práxis Pedagogia. 1. Disponível no site www.educacaoonline.pro.br. Acesso em 2011.

15. PROEX-UFF. UFF cria Escola de Inclusão para preparar futuros profissionais no trato com as diferenças. Disponível no site http://www.noticias.uff.br/noticias/2009/07/escola-inclusao.php, Acesso em 2001.

16. SASSAKI, R. Inclusão implica em transformação. Entrevista ao Jornal da entidade Amigos dos Metroviários Excepcionais. São Paulo, 2005.

17. STAKES, R.; HORNBY, G. Meeting special needs in mainstream schools a practical guide for teachers (2nd ed.) London: David Fulton, 2000. 
18. VIVEIROS, E.R.; CAMARGO, E.P. Ensino de Ciências e Matemática num ambiente inclusivo: pressupostos didáticos e metodológicos. UNESP, 2006. Disponível no site http://www.google.com.br/ url?sa $=\mathrm{t} \&$ source $=$ web $\& \mathrm{ct}=\mathrm{res} \& \mathrm{~cd} \quad=2 \& \mathrm{ved}=0 \mathrm{CAwQ}$ FjAB\&url=http\%3A\%2F\%2Fwww.fqm.feis.unesp.br $\% 2$ Fdvfisica $\% 2$ Fartigo 11 ensinocienciaematematica. doc\&rct=j\&q=SASSAKI $+2005+\&$ ei $=$ szsRS924B $4 \mathrm{Nu}$ Afi_qm4CQ\&usg=AFQjCNGKp7ugkhUbOtvvffUr EP-MR0Gx7A. Acesso em 02 de outubro de 2011.

19. WRIGHT, S. Guide to Designing Tactile Illustrations for Children's Books. American Printing House for the Blind. 2008. Disponível no site http://www.aph.org/ edresearch/illustrations/index.html. Acesso em 01 de outubro de 2011. 
Table 1: Some opinions of the teachers, professors, undergraduate students and the high school blind student about the material analysis after participating in the Escola de Inclusão extension program.

\begin{tabular}{|c|c|}
\hline Participant & Analysis report \\
\hline Teachers and Professors & $\begin{array}{l}\text { Teacher } 1 \text { - "[...] The presentation was a very good experience and an opportunity to learn the } \\
\text { inclusive work on its diversity" } \\
\text { Professor } 1 \text { - "[...] "The presentation of these materials should be maintained. Excellent opportunity } \\
\text { of learning, helps on creating materials and other improvements to our materials." }\end{array}$ \\
\hline $\begin{array}{l}\text { Undergraduate } \\
\text { students }\end{array}$ & $\begin{array}{l}\text { Undergraduate Student } 1 \text { "[...] "I really enjoyed this day because I had many ideas, especially of } \\
\text { other materials to use [...]" } \\
\text { Undergraduate Student } 2 \text { "[...] During the course I had a real sense of how difficult it is to include } \\
\text { students with special needs in our schools. I also notice the lack of information on this subject in our } \\
\text { country, for undergraduate students and even teachers of these schools. All classes and lectures were } \\
\text { very important for our qualification. Now we are able to better meet this challenge of teaching and } \\
\text { learning together with the students. [...]" } \\
\text { Undergraduate Student } 3 \text { "[...] The course was a unique experience for my training. Consider } \\
\text { organizing an event with a well planned and structured methodology of active school caught my } \\
\text { attention [...]" } \\
\text { Undergraduate Student } 4 \text { - "[...] The course was very good, giving an overview in dealing with } \\
\text { students with disabilities. Now I know better how to deal with this student, so I think I am able to } \\
\text { fulfill my role as a teacher regardless my class student special needs [...]" } \\
\text { Undergraduate Student } 5 \text { "[...] In my opinion the course was very useful to encourage inclusion } \\
\text { activities, or alert us to the fact that there are people with different needs that should be considered. } \\
\text { For the formation of a teacher is extremely important to make it able to teach anything to a student } \\
\text { with disability [...]" }\end{array}$ \\
\hline $\begin{array}{l}\text { High school } \\
\text { Blind student }\end{array}$ & $\begin{array}{l}\text { Oral statement about Presentation of the materials - "It has several nice materials. The Solar } \\
\text { System, I never thought it was so big. The material about chemical bonds is also very useful after the } \\
\text { explanation and the story of the frog (ecological theme) was very interesting" } \\
\text { Writing statement about Biological Memory Game analysis - "It was made a detailed analysis } \\
\text { of the game to ensure that Braille was correct and that the material had consistency. It was found } \\
\text { that Braille was written correctly, but the material had no consistency, because the Braille points } \\
\text { were difficult to read. The didactical material should be redone in order to present consistency and } \\
\text { durability." }\end{array}$ \\
\hline
\end{tabular}



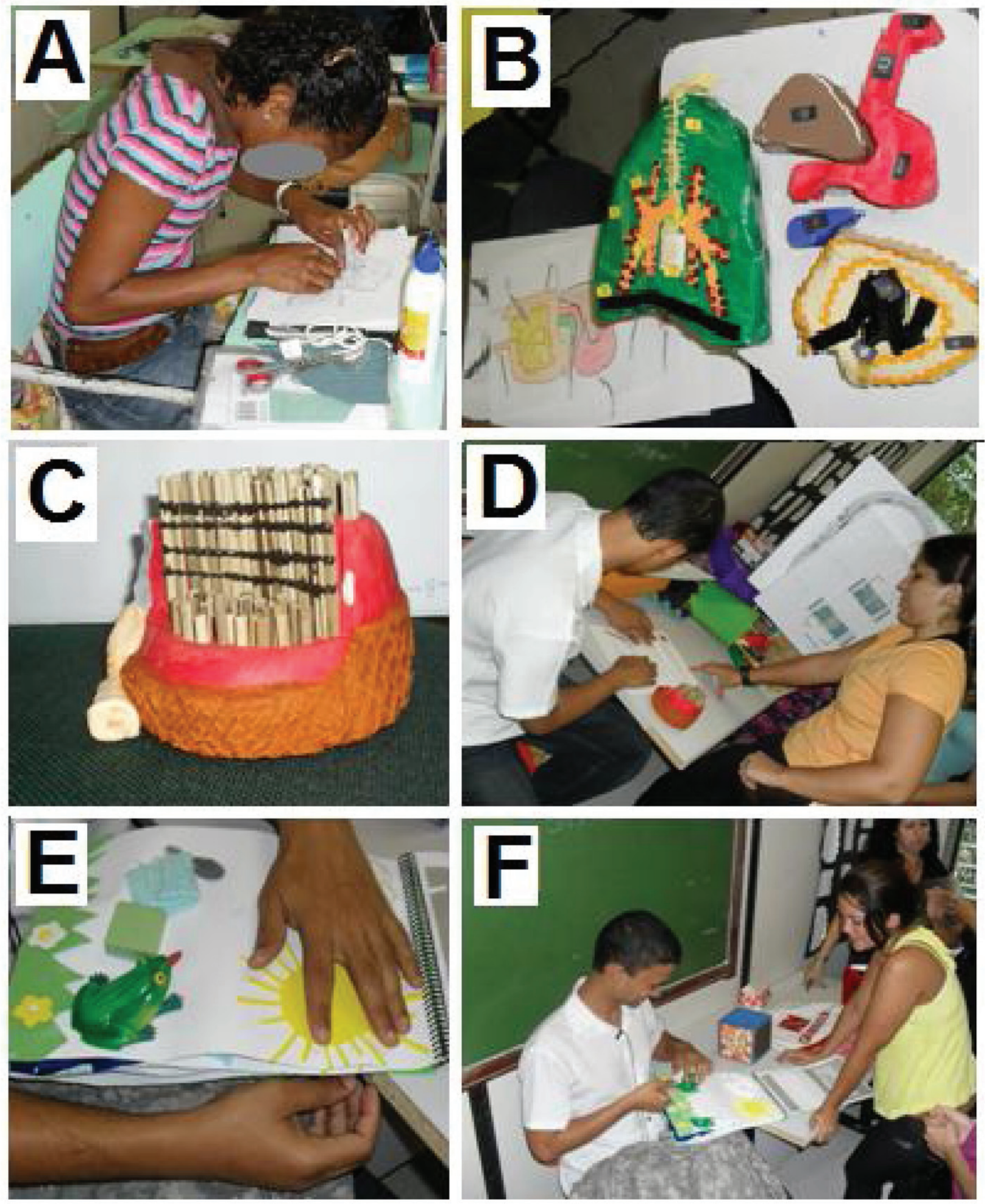

Figure 1: The extension program environment of the Escola de Inclusäo aiming at the inclusion of students with visual impairment. (A) teacher producing biological materials, (B, C, E) materials involving Biology themes and (D, F) high school blind student testing materials . 